\title{
$\underline{\mathrm{O} J \mathrm{ED}}$
}

Volume 4, Issue 1 (2020), pp. 6-9

International Journal of

Entrepreneurship and Economic Issues

ISSN: 2616-0048 Print/ ISSN: 2631-231X Online

\section{Nepalese Teachers' Resilience: Adjusting Learning Context in Pandemic}

\author{
Devi Prasad Adhikari \\ Nilkantha Multiple Campus, Tribhuvan University, Nepal
}

\begin{abstract}
Schools and colleges have been closed due to pandemic. As a result, face-toface teaching and learning has been suspended. This essay explores the changing teaching and learning context and teacher resilience in Nepal since the inception of the Covid-19 pandemic.
\end{abstract}

Keywords: pandemic, context, resilience and virtual learning

The mind is not a vessel to be filled but a fire to be kindled. -Plutarch

These are hard times. Every profession in the world is enthralled with the grotesque situation created by the 2020 pandemic. As a professional teaching for more than two decades, I have deeply observed different but quite exciting situations growing in the teaching and learning context of Nepal. At the time of this writing, educational systems have been locked down, separating teachers and students for more than ten weeks. There is still uncertainty about resuming normal school and college operations. 
However, teachers in Nepal are continuing their profession through online teaching learning practices.

Teacher resilience, defined as the capacity to continue to bounce back, to recover strengths or spirit quickly and efficiently in the face of adversity, is closely allied to a strong sense of vocation, self-efficacy and motivation to teach ( $\mathrm{Gu} \&$ Day, 2007). Work on positive psychology is another important resource for teachers looking to understand and develop well-being in their students (Seligman, 2011) in difficult situations. There has been a particular focus on building learner's individual resilience, mirroring increasing concerns in mainstream general education. Being resilient means coping strategies or a shift in focus from teacher stress and burnout to resilience provides a promising perspective to understand the ways that teachers manage and sustain their motivation and commitment to the learners in times of change (Gu \& Day, 2007).

Teaching is a demanding job in an emerging "age of diversity and sustainability" (Hargreaves \& Fink, 2006). The teachers being locked in their homes are contributing efforts to sustain their profession. Many teachers serving in private schools and colleges have not been paid for last two or three months, however, they have not given up their hope. They are busier in taking virtual classes regularly through apps such as Zoom, Google Classroom, What's App, Google Meet, Moodle and ezTalks Webinar etc. In my own experience, teaching three classes virtually in a day makes me more engaged than teaching five classes regularly in real classrooms. I have to be more sensitive and technically resourceful as I usually record the classes for further purpose and to make it useful for absent and inaccessible learners at the time being. Quality is another important concern. Teachers are committed to it.

It has also been argued that teacher resilience is a 'quality retention' issue (Day \& $\mathrm{Gu}, 2010$ ) with retention of committed, engaged and motivated teachers who, regardless of career stage, continue to develop professionally and maximize their capacity to provide high quality teaching. In current trends with multiple educational levels, online learning resources and activities about teacher resilience may also be developed as a standalone resource or to supplement or complement face-to-face learning. Relational resilience is formed through a web of strong and trusting relationships among practitioners for mutual empowerment, growth and support at the centre of the resilience process $(\mathrm{Gu}, 2014)$. In addition to resilience-based approaches in mainstream education systems, there is an emerging body of research exploring the role of resilience in supporting general self-determination in the face of difficult settings (UNICEF, 2016). 
Masten and Powell (2003) provide a broad-based framework for understanding resilience in a way that is useful for practitioners as well as researchers and policymakers. The trend of being resilient and efforts of engaging in virtual teaching learning among Nepali teaching professionals could be considered for further policy in education in such crisis.

We teachers are coping in such vulnerable times. Vulnerability and resilience are related concept (Buckle, 2006). However, it is important that resilience is not considered as opposite to vulnerability. It is like indispensable fact that teachers can do more than what society expects in such difficult circumstances. In the context of Nepal, it was thought to be hard to conduct virtual classes before the COVID-19 pandemic. However, most of the teachers have been utilizing the impenetrable time fruitfully engaging themselves in distanced teaching and learning processes using different tools. Thus, the learning and teaching context of Nepal has been changed amidst the pandemic. The teachers are adopting the condition of changed scenario of teaching learning dynamics. It is possible due to resiliency, they are expanding their knowledge base. Different factors have contributed to this. Emotion related outcomes include factors such as enjoyment of work, enthusiasm, and passion (Le Cornu, 2013). However, the main factor what I believe is their willingness to revitalize their profession to adapt to the virtual environment. The major outcome during the lock down, the teachers have demonstrated that we can transform unpleasant situations in to hopeful occurrences, even being a part of developing country such as Nepal.

\section{REFERENCES}

Buclke, P. (2006). Assessing social resilience. 88-104. Charles C. Thomas Publication.

Day, C., \& Gu, Q. (2010). The new lives of teachers. Routledge Taylor \& Francis Group.

Gu, Q. \& Day, C. (2007). Teachers' resilience: A necessary condition for effectiveness. Teaching and Teacher Education, 23, 13021316.

$\mathrm{Gu}, \mathrm{Q}$. (2014). The role of relational resilience in teachers' career-long commitment and effectiveness. Teachers and Teaching: Theory and Practice, 20(5), 502-529. http://dx.doi.org/10.1080/13540602.2014.937961.

Hargreaves, A., \& Fink, D. (2006). Sustainable leadership. Jossey- 
Bass.

Le Cornu, R. (2013). Building early career teacher resilience: the role of relation- ships. Australian Journal of Teacher Education, 38(4), 1-16. http://dx.doi.org/ 10.14221/ajte.2013v38n4.4.

Masten, A.S. \& Powell J.L.. (2003). 'A resilience framework for research, policy, and practice' in S.S. Luthar (ed.). Resilience and Vulnerability: Adaptation in the Context of Childhood Adversities. (2nd., pp. 1-25).

Seligman, M. (2011). Flourish: A visionary new understanding of happiness and wellbeing. Free Press.

UNICEF. (2016). Language education and social cohesion (LESC) initiative. UNICEF East Asia and Pacific Regional Office.

Devi Prasad Adhikari, an M. Phil. Graduate is the Head of Department of English, Nilkantha Multiple Campus, Tribhuvan University. His major research interests lie in the area of academic leadership, research and teaching in higher education, and language learning.

Email: deviprasad.adhikari@gmail.com 